DOI: https://doi.org/10.24127/ajpm.v10i3.3713

\title{
ANALISIS KESALAHAN KONSEPTUAL DAN PROSEDURAL SISWA SEKOLAH DASAR DALAM MENGGENERALISASI POLA BILANGAN
}

\author{
Mega Selvia Ayu Devi ${ }^{1}$, Mohammad Faizal Amir ${ }^{2 *}$ \\ 1,2* PGSD Universitas Muhammadiyah Sidoarjo, Indonesia \\ *Corresponding author \\ E-mail: $\quad$ megaselviaayudevi@gmail.com $^{1)}$ \\ faizal.amir@umsida.ac.id ${ }^{2 *}$
}

Received 31 May 2021; Received in revised form 09 September 2021; Accepted 25 September 2021

\begin{abstract}
Abstrak
Tujuan penelitian ini adalah untuk menganalisis kesalahan konseptual dan prosedural siswa sekolah dasar dalam menggeneralisasi pola bilangan. Jenis penelitian ini adalah kualitatif dengan pendekatan studi kasus. Subjek penelitian adalah siswa kelas VI SDN Juwet Kenongo Porong. Teknik typical sampling digunakan untuk memilih tiga subjek dari 24 siswa. Kategori pemilihan subjek didasarkan pada satu siswa yang memiliki tingkat pemecahan masalah paling tinggi, satu siswa yang memiliki tingkat pemecahan masalah sedang, dan satu siswa yang memiliki tingkat pemecahan masalah paling rendah. Metode pengumpulan data menggunakan tes generalisasi pola bilangan, wawancara, dan dokumentasi. Teknik analisis data meliputi reduksi data, penyajian data, dan penarikan kesimpulan. Hasil penelitian menunjukkan bahwa siswa dengan tingkat pemecahan masalah rendah dan sedang cenderung melakukan kesalahan konseptual. Sedangkan, siswa dengan tingkat pemecahan masalah tinggi cenderung hanya melakukan kesalahan prosedural. Hasil peneltian ini memberikan keyakinan bahwa siswa sekolah dasar mampu melakukan generalisasi pola bilangan dengan pendekatan pola figural atau gambar, meskipun dengan beberapa bentuk kesalahan konseptual maupun prosedural. Hal ini berimplikasi pada para pendidik atau akademisi untuk dapat meminimalisir kesalahan siswa sekolah dasar dalam menggeneralisasi pola, melalui stimulisasi pengajaran berbasis masalah yang tidak hanya bersifat pengetahuan prosedural, namun lebih bersifat pengetahuan konseptual.
\end{abstract}

Kata kunci: Generalisasi Pola; Kesalahan Konseptual dan Prosedural; Tingkat Pemecahan Masalah.

\begin{abstract}
This research aimed to analyze the conceptual and procedural errors of elementary school students in generalizing number patterns. This type of research is qualitative with a case study approach. The research subjects were students of grade VI SDN Juwet Kenongo Porong. A typical sampling technique was used to select three subjects from 24 students. The category of subject selection is based on one student who has the highest level of problem-solving, one student who has a moderate level of problemsolving, and one student who has the lowest level of problem-solving. The data collection method uses a number of pattern generalization test, interviews, and documentation. Data analysis techniques include data reduction, data presentation, and concluding. The results showed that students with low and moderate levels of problem-solving tended to make conceptual errors. Meanwhile, students with a high level of problem-solving managed only to commit procedural errors. This study provides confidence that elementary school students can generalize number patterns with a figural pattern or image pattern approach, although with some forms of conceptual and procedural errors. This has implications for educators or academics to be able to minimize errors of elementary school students in generalizing patterns through stimulating problem-based teaching, which is procedural knowledge and more conceptual knowledge.
\end{abstract}

Keywords: Conceptual and Procedural Errors; Generalization of Patterns; Problem Solving Level.

This is an open access article under the Creative Commons Attribution 4.0 International License 
DOI: https://doi.org/10.24127/ajpm.v10i3.3713

\section{PENDAHULUAN}

Salah satu pengetahuan aljabar yang perlu dimiliki siswa adalah pengetahuan konseptual dan prosedural. Pengetahuan konseptual dalam matematika adalah pengetahuan dasar yang berkaitan dengan informasi fakta, konsep, kemampuan dan prinsip (Badjeber \& Mailili, 2019). Pengetahuan prosedural terdiri dari aturan dan algoritma atau prosedur yang digunakan untuk menyelesaikan matematika (Hiebert, 1986). Pengetahuan konseptual dan prosedural sangat penting bagi siswa sekolah dasar agar terhindar dari kesalahan konseptual dan prosedural pada jenjang sekolah berikutnya. Hal ini dapat dilakukan dengan penguatan konsep dasar matematis dan prosedur penyelesaian soal yang lebih sistematis (Khashan, 2014). Namun, kesalahan konseptual dan prosedural dalam menyelesaikan soal seringkali terjadi pada setiap jenjang sekolah (Wiest \& Amankonah, 2021).

Kesalahan konseptual adalah kesalahan dalam menentukan dan menggunakan teorema untuk menyelesaikan masalah. Sedangkan, kesalahan prosedural adalah kesalahan dalam menggunakan aturan untuk melakukan penyelesai-an (Winarso \& Toheri, 2021). Jenis kesalahan prosedural terbagi menjadi empat kategori diantaranya yaitu kesalahan operasi, kesalahan komputasi, kesalahan algoritmik, dan kesalahan jawaban acak (Lenz dkk., 2020).

Siswa sekolah dasar seringkali mengalami kesalahan saat menentukan pola bilangan dan mengekspresikan aljabar. Dalam hal ini, siswa tidak memperhatikan instruksi atau tidak mampu mengidentifikasi pola bilangan yang sebelumnya (Apsari, 2015). Siswa sekolah dasar juga mengalami kesulitan dan kegagalan saat menghitung banyak pola bilangan ke-n (Rusdiana dkk., 2017). Hal serupa ditemukan oleh Bongala (2020) yaitu siswa sekolah dasar mengalami kesulitan saat memvisualisasikan masalah dan mengekspresikan pola ke dalam simbol matematika. Hal ini mengakibatkan kesalahan siswa dalam menggeneralisasi pola bilangan ke-n.

Pola bilangan merupakan salah satu cakupan topik aljabar yang didalamnya melibatkan proses generalisasi. Menggeneralisasi pola adalah acuan yang dijadikan para peneliti sebagai pendekatan untuk meningkatkan penalaran aljabar siswa (Cavey \& Lowenthal, 2016). Sebagaimana hasi penelitian Girit \& Akyuz (2016) menjelaskan bahwa melalui penggunaan soal pola sebagai instrumen pengukur generalisasi aljabar dapat memberikan pengalaman siswa untuk mengonstruk dan menjustifikasi generalisasi aljabar saat memecahkan pola bilangan.

Siswa sekolah dasar banyak melakukan kesalahan dalam menggeneralisasi pola bilangan untuk merumuskan pola ke-n (Serbin dkk., 2020). Aljabar melalui generalisasi pola bilangan dikenal secara intuitif pada kurikulum sekolah dasar. Intuitif berarti, pola bagi siswa sekolah dasar diidentifikasi melalui pola bilangan secara visual atau figural yang merupakan representasi dari benda kongkrit (Gunawan dkk., 2019).

Generalisasi pola bilangan tercakup dalam tiga aspek berpikir aljabar, yaitu menggeneralisasi aritmatika, penggunaan model matematika, perkembangan bahasa aljabar (Apsari, 2015). Generalisasi pola di tingkat sekolah dasar dapat dipandang sebagai pemberian pengalaman belajar dengan struktur bilangan yang biasanya dikenal dengan 
istilah pra-aljabar. Hal ini bukan maksud mentransfer kurikulum sekolah menengah ke sekolah dasar, tetapi untuk memberikan perubahan secara perlahan kepada siswa agar belajar mengembangkan kemampuan berpikir dan bernalar aljabar (Ocal, 2017). Dengan demikian, siswa sekolah dasar memiliki kesempatan lebih dini untuk mengenal hubungan antar bilangan yang memiliki hubungan pola bilangan yang belum diketahui.

Beberapa penelitian terdahulu terkait kesalahan konseptual dan prosedural di sekolah dasar dalam menggeneralisasi pola, diantaranya oleh Mouhayar \& Jurdak (2016) menemukan siswa sekolah dasar cenderung mengalami kegagalan dalam menggambarkan pola figural dari pola numerik suku ke-n. Andini \& Suryadi (2017) menemukan siswa sekolah dasar memiliki hambatan dalam menghubungkan pola gambar dengan pola bilangan dan siswa melakukan kesalahan dalam menggeneralisasi pola kuadrat. Radford (2018) menemukan siswa sekolah dasar kelas 4 hingga 6 dapat menggeneralisasi pola dengan prosedur dan aturan, namun kesalahan siswa terjadi karena minimnya pemahaman konseptual. Papadopoulou (2020) menemukan kesalahan yang biasa dilakukan siswa sekolah dasar adalah menghubungkan antar aturan dan serangkaian elemen dalam pola.

Berdasarkan penelitian-penelitian terdahulu didapatkan bahwa kegagalan siswa sekolah dasar dalam menggeneralisasi pola dikarenakan kesalahan konseptual dan prosedural. Selain itu, penelitian-penelitian tersebut belum menganalisis secara khusus mengenai kesalahan konseptual dan prosedural apa saja yang dilakukan siswa sekolah dasar dalam menggeneralisasi pola. Dalam penelitian ini, bentuk-bentuk kesalahan konseptual dan prosedural dalam menggeneralisasi pola dianalisis untuk mendapatkan gambaran mendetail mengenai penyebab kegagalan siswa melakukan generalisasi pola ke-n. Hal ini dimungkinkan, meskipun siswa sekolah dasar melakukan kesalahan penyelesaian. Namun siswa sekolah dasar memiliki kemampuan untuk melakukan generali-sasi pola dengan menggunakan representasi seperti gerak tubuh, kata-kata, dan simbol aritmatika untuk menyampaikan ekspresi umum (Rivera, 2018).

Performa generalisasi pola dipengaruhi juga oleh tingkat pemecahan masalah siswa (Ling dkk., 2019). Namun, terdapat celah pada penelitian terdahulu bahwa pentingnya generalisasi pola bilangan pada siswa sekolah dasar belum ada yang bisa menjawab tentang apa saja bentuk kesalahan konseptual dan prosedural yang terjadi dengan meninjau tingkat pemecahan masalah siswa. Dengan demikian, tujuan penelitian ini adalah untuk menganalisis kesalahan konseptual dan prosedural siswa sekolah dasar dalam menggeneralisasi pola ditinjau dari tingkat kemampuan pemecahan masalah.

\section{METODE PENELITIAN}

Metode penelitian ini adalah kualitatif dengan pendekatan studi kasus (case study), yaitu mempelajari fenomena kasus secara mendalam untuk memperoleh informasi (Creswell, 2012). Tahapan studi kasus yang dilakukan yaitu menetapkan tingkat pemecahan masalah, memilih subjek pada setiap tingkat pemecahan masalah, dan menganalisis kasus berupa kesalahan konseptual dan prosedural siswa sekolah dasar dalam menggeneralisasi pola pada masingmasing tingkat pemecahan masalah subjek. 
DOI: https://doi.org/10.24127/ajpm.v10i3.3713

Penelitian ini dilakukan di SDN Juwet Kenongo Porong Sidoarjo, kelas VI yang berjumlah 24 siswa. Teknik penentuan subjek menggunakan typical sampling dalam penelitian kualitatif, yaitu pengambilan subjek dengan maksud tertentu yang memiliki situasi unfamiliar (tidak biasa) (Creswell, 2012). Sebanyak tiga subjek sekolah dasar dalam penelitian ini ditentukan dalam tiga kategori yaitu satu siswa yang memiliki tingkat pemecahan masalah paling tinggi, satu siswa yang memiliki tingkat pemecahan masalah sedang, dan satu siswa yang memiliki tingkat pemecahan masalah paling rendah. Ketiga subjek tersebut dimaksudkan untuk dianalisis bentukbentuk kesalahan konseptual dan prosedural yang dilakukan dalam menggeneralisasi pola. Situasi unfamiliar yang dimaksud adalah kondisi analisis kesalahan konseptual dan prosedural dalam menggeneralisasi pola yang tidak biasa dilakukan pada siswa sekolah dasar.

Instrumen penelitian ini meliputi tes generalisasi pola dan pedoman wawancara. Tes generalisasi pola numerik dari pola figural yang terdiri dari dua butir soal yang dimodifikasi dari soal pola dan pemecahan masalah oleh Bennett dkk. (2012) untuk mengonstruk dan menjustifikasi generalisasi pola bilangan siswa (Lihat Tabel 1). Dalam penyusunan soal tes ini, memperhitungkan aspek kognitif dari taksonomi Bloom, yaitu kategori C1 (mengingat), C3 (mengaplikasikan), C4 (menganalisis), C6 (mencipta) (Krathwohl, 2002). Pedoman Wawancara berisi pertanyaanpertanyaan tentang bentuk-bentuk kesalahan konseptual dan prosedural yang dilakukan siswa untuk memperdalam hasil pekerjaan tes siswa.
Teknik pengumpulan data penelitian ini menggunakan tes, wawancara, dan dokumentasi. Tes generalisasi pola diberikan kepada siswa mengelompokkan siswa berdasarkan tingkat pemecahan masalahnya, lalu dianalisis bentukbentuk kesalahan konseptual dan prosedural dalam menggeneralisasi pola pada siswa terpilih. Wawancara dilakukan secara semi terstruktur berdasarkan indikator kesalahan konseptual dan prosedural, serta mengikuti jawaban kesalahan siswa. Dokumentasi dilakukan dengan merekan proses penyelesaian dan wawancara siswa.

Tabel 1. Tes generalisasi pola

\begin{tabular}{clc}
\hline No & \multicolumn{1}{c}{ Soal tes } \\
\hline 1 & Tentukan banyak ubin pada pola \\
& bilangan $k e-6$ dan $k e-25$ \\
& Tentukan pola bilangan $k e-n$.
\end{tabular}
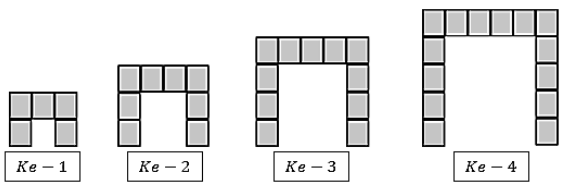

2 Tentukan banyak lingkaran pada pola $k e-5, k e-9$, dan $k e-14$ Tentukan pola bilangan $k e-n$

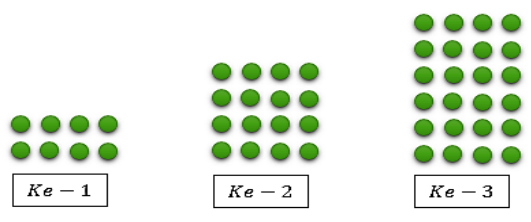

Adapun sebelum melakukan analisis terhadap menganalisis kesalahan konseptual maupun kesalahan prosedural, total skor pemecahan masalah yang diperoleh siswa dikonversi pada interval nilai 0-100 dan dikategorikan berdasarkan kategori skor seperti pada Tabel 2. 
DOI: https://doi.org/10.24127/ajpm.v10i3.3713

Tabel 2. Kategori skor tingkat pemecahan masalah

\begin{tabular}{ccc}
\hline No & $\begin{array}{c}\text { Tingkat pemecahan } \\
\text { masalah }\end{array}$ & Interval \\
\hline 1 & Rendah & $0 \leq$ skor $\leq 31$ \\
2 & Sedang & $31<$ skor $\leq 69$ \\
3 & Tinggi & $69<$ skor $\leq 100$ \\
\hline
\end{tabular}

(Amir, 2015)

Dalam penelitian ini, pengetahuan konseptual dapat diketahui apabila siswa dapat membedakan contoh atau non-contoh, konsep, menyajikan ide dalam bentuk model, gambar, serta grafik. Sementara pengetahuan prosedural dapat didefinisikan dalam dua jenis pengetahuan yaitu, a) hubungan antara simbol individu dengan sistem dan b) aturan atau prosedur untuk memecahkan masalah matematika (Star \& Stylianides, 2013). Dalam penelitian ini, jenis pengetahuan prosedural dipandang sebagaimana yang kedua yaitu suatu aturan maupun langkah yang digunakan untuk menyelesaikan masalah matematika. Berdasarkan definisi pengetahuan konseptual dan prosedural menurut Crooks \& Alibali (2014) dan Star \& Stylianides (2013) dibuat tabel indikator pengetahuan konseptual dan prosedural untuk menganalisis kesalahan konseptual dan prosedural siswa sekolah dasar dalam menggeneralisasi pola ditunjukkan pada Tabel 3.

Tabel 3. Indikator pengetahuan konseptual dan prosedural

\begin{tabular}{|c|c|c|c|c|}
\hline \multirow{2}{*}{ No } & \multirow{2}{*}{ Pengetahuan } & \multirow{2}{*}{ Deskriptor } & \multicolumn{2}{|c|}{ Indikator } \\
\hline & & & Pengetahuan & Kesalahan \\
\hline \multirow[t]{7}{*}{1} & Konseptual & $\begin{array}{l}\text { Memahami dan } \\
\text { menjelaskan } \\
\text { konsep } \\
\text { matematika }\end{array}$ & $\begin{array}{l}\text { Membedakan contoh dan } \\
\text { bukan contoh }\end{array}$ & $\begin{array}{l}\text { Menggunakan } \\
\text { matematika yang tertera } \\
\text { pada soal hanya sebagian } \\
\text { saja, tidak sepenuhnya } \\
\text { dijadikan contoh dalam } \\
\text { pemecahan masalah }\end{array}$ \\
\hline & & & $\begin{array}{l}\text { Mengidentifikasi konsep- } \\
\text { konsep matematika, }\end{array}$ & $\begin{array}{l}\text { Menghitung penjumlahan } \\
\text { saat mencari pola } k e-n\end{array}$ \\
\hline & & & $\begin{array}{l}\text { operasi hitung, dan } \\
\text { hubungannya }\end{array}$ & kurang teliti \\
\hline & & \begin{tabular}{lr}
\multicolumn{2}{l}{ Menghubungkan } \\
informasi & yang \\
diperoleh & dengan
\end{tabular} & $\begin{array}{l}\text { Menyebutkan konsep apa } \\
\text { yang ada pada soal }\end{array}$ & $\begin{array}{l}\text { Menggunakan konsep pada } \\
\text { soal tidak secara } \\
\text { keseluruhan }\end{array}$ \\
\hline & & $\begin{array}{l}\text { domain atau } \\
\text { konsep }\end{array}$ & $\begin{array}{l}\text { Menghubungkan konsep } \\
\text { yang ada di soal dengan } \\
\text { konsep yang sudah } \\
\text { diperoleh sebelumnya }\end{array}$ & $\begin{array}{l}\text { Menghubungkan konsep } \\
\text { dari hasil yang diperoleh } \\
\text { saat memecahkan masalah, } \\
\text { tidak mengaitkan dengan } \\
\text { konsep yang ditemui } \\
\text { sebelumnya }\end{array}$ \\
\hline & & $\begin{array}{l}\text { Menyajikan } \\
\text { konsep dalam } \\
\text { bentuk lain }\end{array}$ & $\begin{array}{l}\text { Menyajikan konsep yang } \\
\text { dipahami dalam bentuk } \\
\text { gambar atau grafik }\end{array}$ & $\begin{array}{l}\text { Menyajikan konsep pola } \\
\text { bilangan yang berupa } \\
\text { gambar, namun tidak } \\
\text { dilanjutkan untuk mencari } \\
\text { pola ke-n yang belum } \\
\text { diketahui }\end{array}$ \\
\hline & & & $\begin{array}{l}\text { Memodelkan konsep yang } \\
\text { sudah dipahami tersebut } \\
\text { dan menerjemahkannya ke } \\
\text { dalam ide }\end{array}$ & $\begin{array}{l}\text { Menuliskan ekspresi aljabar } \\
\text { kurang tepat, berpatokan } \\
\text { pada hasil pola bilangan } \\
k e-n \text { yang diperoleh }\end{array}$ \\
\hline
\end{tabular}


DOI: https://doi.org/10.24127/ajpm.v10i3.3713

\begin{tabular}{|c|c|c|c|c|}
\hline \multirow{2}{*}{ No } & \multirow{2}{*}{ Pengetahuan } & \multirow{2}{*}{ Deskriptor } & \multicolumn{2}{|c|}{ Indikator } \\
\hline & & & Pengetahuan & Kesalahan \\
\hline \multirow[t]{4}{*}{2} & Prosedural & $\begin{array}{l}\text { Membuat aturan } \\
\text { umum, fakta, dan } \\
\text { definisi }\end{array}$ & $\begin{array}{lr}\text { Memilih prosedur } & \text { yang } \\
\text { diperlukan } & \text { untuk } \\
\text { menyelesaikan } & \text { suatu } \\
\text { permasalahan } & \end{array}$ & $\begin{array}{l}\text { Memilih prosedur tidak } \\
\text { secara runtut }\end{array}$ \\
\hline & & & $\begin{array}{ll}\text { Menyusun } & \text { suatu tindakan } \\
\text { dalam } & \text { menyelesaikan } \\
\text { masalah } & \end{array}$ & $\begin{array}{l}\text { Melakukan tindakan yang } \\
\text { sudah disusun sebelumnya, } \\
\text { tetapi tindakan tersebut } \\
\text { tidak diselesaikan dengan } \\
\text { baik }\end{array}$ \\
\hline & & $\begin{array}{l}\text { Menyelesaikan } \\
\text { masalah dengan } \\
\text { aturan yang sudah } \\
\text { dibuat }\end{array}$ & $\begin{array}{lr}\text { Menerapkan } & \text { atau } \\
\text { menggunakan } & \text { simbol, } \\
\text { keadaan dan proses untuk } \\
\text { menyelesaikan masalah } \\
\text { matematika }\end{array}$ & $\begin{array}{l}\text { Menyelesaikan proses } \\
\text { pengerjaan secara tidak urut } \\
\text { sesuai aturan pola yang } \\
\text { telah dipilih }\end{array}$ \\
\hline & & & $\begin{array}{lr}\text { Menjelaskan } & \text { atau } \\
\text { membenarkan } & \text { satu cara } \\
\text { memecahkan } & \text { masalah } \\
\text { yang diberikan } & \end{array}$ & $\begin{array}{l}\text { Menggunakan satu cara } \\
\text { untuk menyelesaikan } \\
\text { masalah, tidak menentukan } \\
\text { cara lain untuk mencari } \\
\text { jawaban yang benar }\end{array}$ \\
\hline
\end{tabular}

Teknik triangulasi meliputi hasil kerja subjek penelitian, wawancara, dan observasi. Analisis data penelitian meliputi reduksi data, penyajian data, dan penarikan kesimpulan. Analisis data didasarkan dari hasil pekerjaan siswa yang dikonfirmasi secara mendalam melalui wawancara dan observasi proses penyelesaian siswa. Adapun wawancara dan observasi direkam dengan menggunakan menggunakan handphone.

\section{HASIL DAN PEMBAHASAN}

Berdasarkan hasil pekerjaan siswa, diperoleh masing-masing satu siswa yang memiliki tingkat pemecahan masalah tertinggi, sedang, dan paling rendah. Dalam penelitian ini, siswa dengan kategori tingkat pemecahan masalah paling rendah dikodekan sebagai subjek 1 (S1), siswa dengan kategori tingkat pemecahan masalah sedang dikodekan sebagai subjek 2 (S2), sementara siswa dengan kategori tingkat pemecahan masalah paling tinggi dikodekan sebagai subjek 3 (S3).
1. Kategori Pemecahan Masalah Rendah

Gambar 1 dan Gambar 2 merupakan hasil pekerjaan siswa pada kategori tingkat pemecahan masalah rendah yang dikodekan sebagai subjek 1 (S1), kesalahan yang dilakukan adalah kesalahan konseptual.

a. Kesalahan konseptual ke-1 pada soal 1

Pada Gambar 1, S1 melakukan kesalahan konseptual khususnya konsep operasi hitung matematika untuk menghitung pola $k e-6$ dan pola $k e-25$. Hal ini karena S1 kurang konsentrasi pada proses menghitung. S1 tidak sepenuhnya memahami konsep pola pada soal, untuk menentukan pola $k e-6$, S1 mengekspresikan dalam bentuk gambar. Pernyataan tersebut diperkuat dengan hasil wawancara yang diperoleh, S1 mengatakan: "Saya menggambar pola, kemudian saya menghitung setiap tingkat ubin dikali 3 dikurangi 1". 
DOI: https://doi.org/10.24127/ajpm.v10i3.3713

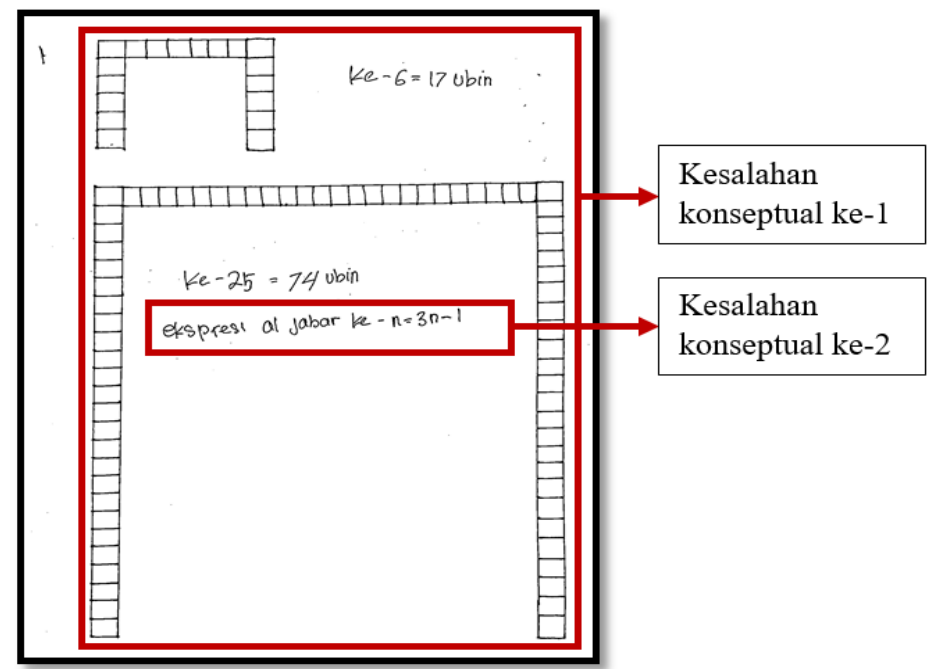

Gambar 1. Pekerjaan S1 pada soal 1

b. Kesalahan konseptual (2) pada soal 1

Pada Gambar 1, S1 melakukan kesalahan konseptual saat menuliskan ekspresi aljabar $k e-n=3 n-1$. Penulisan ekspresi aljabar $k e-n$ dinyatakan salah karena adanya kesalahan perhitungan pada pola $k e-$ 6. Pernyataan tersebut diperkuat dengan hasil wawancara yang diperoleh, S1 mengatakan: "Saya menuliskan ekspresi aljabar $k e-n=3 n-1 "$.

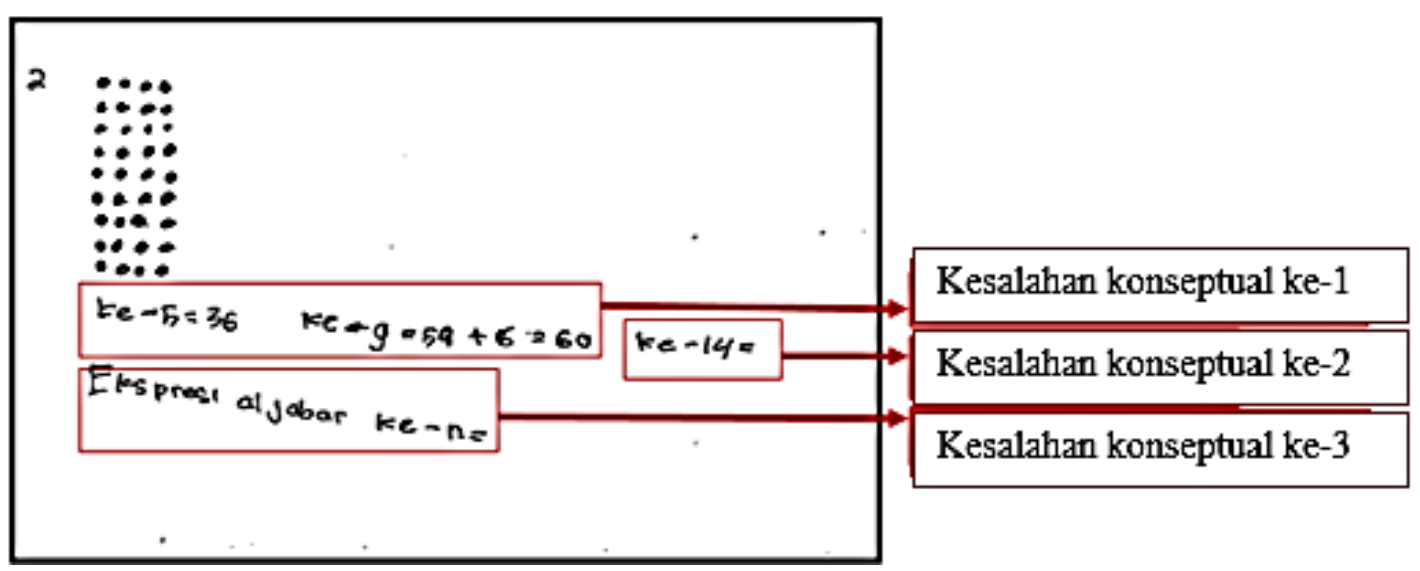

Gambar 2. Pekerjaan S1 pada soal 2

c. Kesalahan konseptual (1) pada soal 2

Pada Gambar 2, S1 melakukan kesalahan konseptual operasi hitung penjumlahan saat menghitung pola $k e-5$ dan pola $k e-9$. S1 menghitung pola $k e-9$ mengacu pada hasil pola $k e-5$. Namun, hasil yang diperoleh dinyatakan salah. Pernyataan tersebut diperkuat dengan hasil wawancara yang diperoleh, S1 mengatakan: "Saya menghitung pola $k e-5$ dan pola $k e-9$ melalui gambar".

d. Kesalahan konseptual (2) pada soal 2 Pada Gambar 2, S1 melakukan kesalahan konseptual pada konsep operasi hitung saat menghitung pola bilangan $k e-n$. S1 tidak menghitung pola $k e-14$. Sehingga pada pola $k e-14$ belum terjawab. Pernyataan tersebut diperkuat dengan hasil 
DOI: https://doi.org/10.24127/ajpm.v10i3.3713

wawancara yang diperoleh, S1 mengatakan: "Saya menghitung pola $k e-5$ dan pola $k e-9$ saja, tidak menghitung pola $k e-14$.

e. Kesalahan konseptual (3) pada soal 2

Pada Gambar 2, S1 melakukan kesalahan konseptual pada konsep ekspresi aljabar saat menuliskan ekspresi aljabar. S1 tidak menuliskan ekspresi aljabar $k e-n$. Hal ini karena $\mathrm{S} 1$ belum menentukan pola $k e-14$. S1 hanya menentukan pola $k e-5$ dan $k e-9$. Pernyataan tersebut diperkuat dengan hasil wawancara yang diperoleh, S1 mengatakan: "Saya tidak menuliskan ekspresi aljabarnya, karena saya belum menentukan pola ke - 14".

2. Kategori Pemecahan Masalah Sedang

Gambar 3 dan Gambar 4 menunjukkan hasil pekerjaan dan kesalahan siswa pada kategori tingkat pemecahan masalah sedang yang dikodekan sebagai subjek 2 (S2).

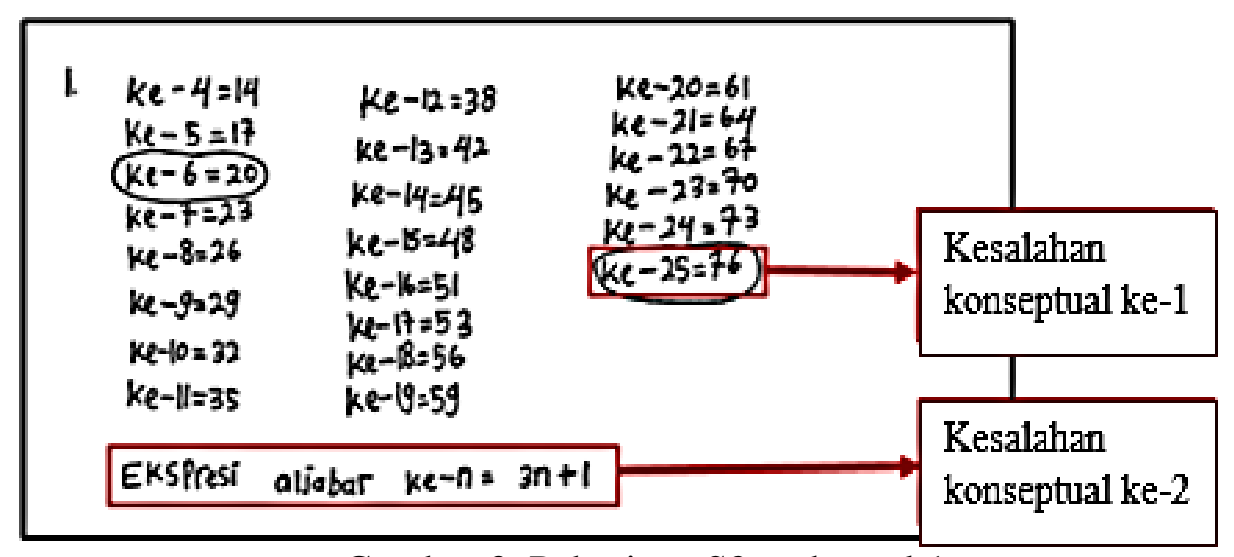

Gambar 3. Pekerjaan S2 pada soal 1

a. Kesalahan konseptual (1) pada soal 1 Pada Gambar 3, S2 melakukan kesalahan konseptual pada konsep operasi hitung selama menghitung penjumlahan pada pola bilangan $k e-$ $n$. S2 menghitung pola secara runtut, dengan menuliskan pola mulai dari pola $k e-4$ hingga pola $k e-25$ untuk menentukan pola $k e-6$ dan pola $k e-25$. Namun, adanya kesalahan hasil pada pola $k e-25$. Pernyataan tersebut diperkuat dengan hasil wawancara yang diperoleh, S2 mengatakan: "Saya menghitung mulai pola $k e-4$ hingga pola $k e-25$ dengan menambahkan 3 angka pada setiap tingkatan pola bilangan, sehingga jawaban banyak pola $k e-6=20$ dan $k e-25=76 "$. b. Kesalahan konseptual (2) pada soal 1 Pada Gambar 3, S2 melakukan kesalahan konseptual pada konsep ekspresi aljabar dalam menuliskan ekspresi aljabar pola $k e-n$. S2 menuliskan ekspresi aljabar dari hasil menentukan pola $k e-6$ dan pola $k e-25$. S2 mengekspresikan aljabar pola $k e-n=3 n+1$. Pernyataan tersebut diperkuat dengan hasil wawancara yang diperoleh, S2 mengatakan: "Saya menuliskan ekspresi aljabar $k e-n=3 n+1$ dari hasil perhitungan pola $k e-6$ dan pola $k e-25$. 


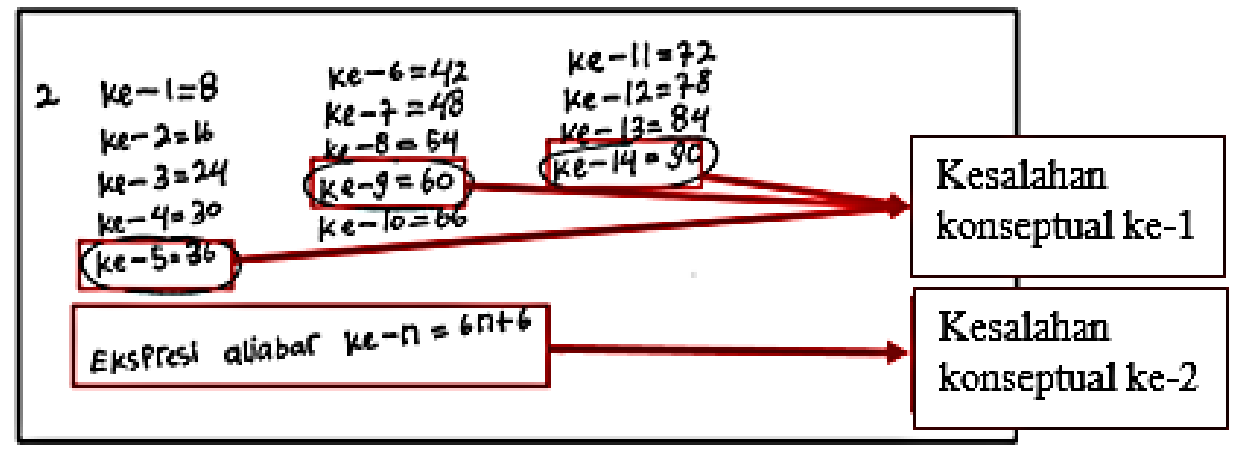

Gambar 4. Pekerjaan S2 pada soal 2

c. Kesalahan konseptual (1) pada soal 2

Pada Gambar 4, S2 melakukan kesalahan konseptulal pada konsep operasi hitung pola $k e-5$, $k e-9$, dan $k e-14$. Siswa menghitung pola secara runtut, dengan menuliskan pola mulai dari pola $k e-4$ hingga pola $k e-25$ untuk menentukan pola $k e-6$ dan pola $k e-25$. Namun, adanya ketidak telitian pada perhitungan setiap langkah pola sehingga menghasilkan jawaban salah pada pola $k e-5$, ke-9, dan $k e-14$. Pernyataan tersebut diperkuat dengan hasil wawancara yang diperoleh, S2 mengatakan: "Saya menambahkan angka 6 pada setiap tingkat untuk menghitung pola $k e-n$, hasil pada pola $k e-5=36$, pola $k e-9=60$, dan pola $k e-14=90$ ".

d. Kesalahan konseptual (2) pada soal 2 Pada Gambar 4, S2 melakukan kesalahan pada konsep ekspresi aljabar saat menuliskan ekspresi aljabar pola $k e-n$. S2 menuliskan ekspresi aljabar dari hasil menentukan pola $k e-5$, $k e-9, \quad$ dan $\quad k e-14 . \quad \mathrm{S} 2$ mengekspresikan aljabar pola $k e-n=$ $6 n+6$. Pernyataan tersebut diperkuat dengan hasil wawancara yang diperoleh, S2 mengatakan: "Saya mengekspresikan aljabarnya $6 n+6$ ".
3. Kategori Pemecahan Masalah Tinggi

Pada kategori kemampuan pemecahan masalah tingkat tinggi diwakili oleh siswa yang diberi kode sebagai subjek 3 (S3). Indikasi adanya kesalahan prosedural yang dilakukan oleh S3 dapat dilihat dari hasil atau jawaban S3 terhadap masalah yang diberikan.

S3 melakukan kesalahan prosedural pada aturan pola, S3 menentukan pola dengan menuliskan mulai dari pola $k e-1$ hingga pola $k e-14$. S3 tidak melaksanakan tindakan yang telah disusun sebelumnya dengan baik hingga proses selanjutnya untuk mencari pola $k e-25$. S3 tidak melanjutkan proses untuk mencari pola $k e-25$. Pernyataan tersebut diperkuat dengan hasil wawancara yang diperoleh, S3 mengatakan: "Saya mencari pola secara urut dengan menuliskan pola $k e-1=2+1+2=$ 5 , pola $k e-2=3+2+3=8$, pola $k e-3=4+3+4=11 \quad$ dan seterusnya untuk menentukan pola $k e-6$ dan pola $k e-25$. Tetapi, saya tidak melanjutkan mencari pola $k e-25$ ". Hasil analisis tersebut didasarkan pada Hasil pekerjaan S3 yang disajikan pada Gambar 5. 
DOI: https://doi.org/10.24127/ajpm.v10i3.3713

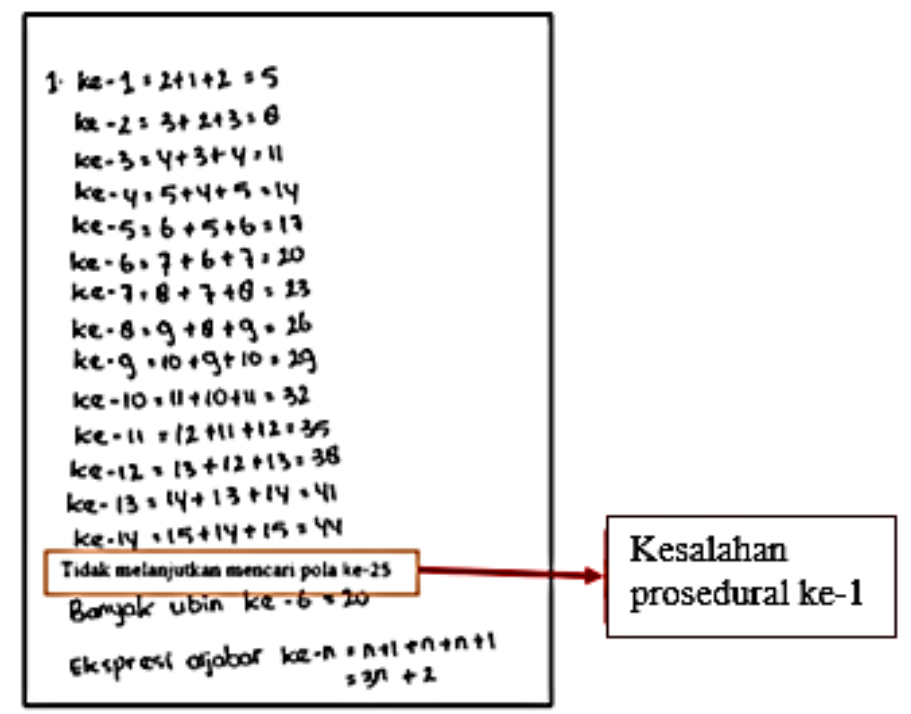

Gambar 5. Pekerjaan S3 pada soal 1

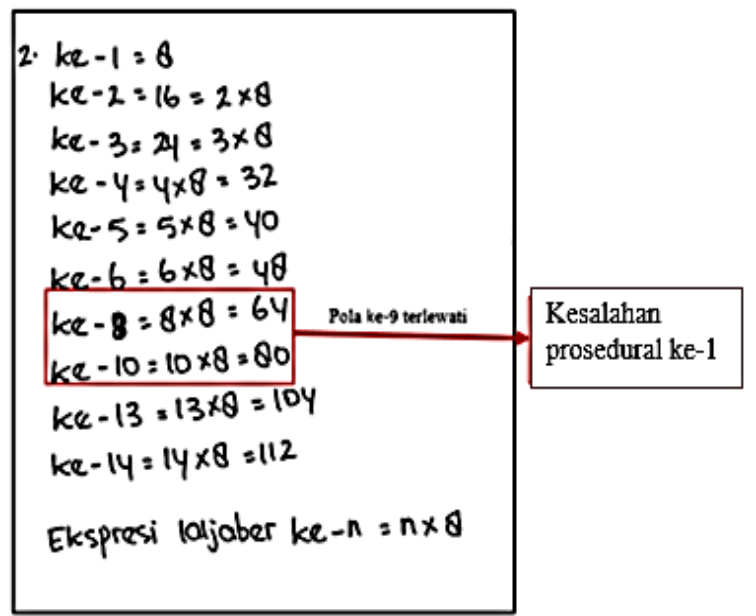

Gambar 6. Pekerjaan S3 pada soal 2

Gambar 6 menunjukkan pekerjaan S3 dengan kesalahan prosedural pada soal nomor 2. S3 melakukan kesalahan prosedural saat menentukan pola $k e-$ 5, ke-9, dan $k e-14$. S3 tidak menggunakan aturan pola yang dipilih sebelumnya dengan baik. Pada pola $k e-9$, ke -11 , dan $k e-12$ terlewati dan tidak terjawab. Pernyataan tersebut diperkuat dengan hasil wawancara yang diperoleh, S3 mengatakan: "Saya menuliskan secara urut dari pola $k e-1=8, \quad k e-2=16 \quad$ yang diperoleh dari $2 \times 8$, dan seterusnya hingga pola $k e-14$, tetapi terdapat ketidak telitian saat saya menuliskan pola $k e-6$, pola $k e-8$, $k e-10$, $k e-13$, ke - 14".

Hasil penelitian menunjukkan bahwa siswa sekolah dasar mampu menggeneralisasi pola bilangan dengan pendekatan pola figural atau gambar, meskipun pada siswa dengan tingkat pemecahan rendah sekalipun. Proses membuat representasi gambar untuk mengidentifikasi pola bilangan adalah salah satu alternatif yang dapat dilakukan siswa dalam menyelesaikan masalah (Al-Mutawah dkk., 2019; Levin, 2018; Wiest \& Amankonah, 
2021; Zulnaidi \& Zakaria, 2012). Dalam hal menghitung atau menentukan pola $k e-n$ serta menuliskan ekspresi aljabar $k e-n$, siswa sekolah dasar mempunyai karakteristik yang berbeda. Menghitung pola juga diperlukan keterampilan seperti menguasai operasi hitung dan ketelitian, agar tidak terjadi kesalahan menghitung. Kesalahan menghitung merupakan salah satu komponen yang menyebabkan siswa melakukan kesalahan (Elif dkk., 2015; Rachmawati dkk., 2021; Stewart dkk., 2017; Winarso \& Toheri, 2021).

Siswa dengan tingkat pemecahan masalah sedang juga melakukan kesalahan dengan tidak teliti dalam menghitung pola $k e-n$. Kesalahan pada operasi hitung pola bilangan yang kurang teliti saat menentukan banyak pola bilangan dan mengonstruk pola bilangan ke dalam ekspresi aljabar dapat mempengaruhi hasil jawaban yang diperoleh (Gunawan dkk., 2019; Rittle-Johnson \& Schneider, 2014).

Siswa dengan kategori tinggi tidak menentukan pola dengan teliti hingga terdapat pola yang tidak dapat dilanjutkan. Ketidaktelitian juga ditemukan pada penelitian Dintarini dkk (2018) dan Khashan (2014). Pada saat menuliskan ekspresi aljabar melalui pola bilangan diperlukan pengetahuan tentang menggeneralisasi pola. Penggunaan pola dalam proses ekspresi aljabar adalah salah satu aspek dalam menyelesaikan masalah (Levin, 2018; Rittle-Johnson \& Schneider, 2014).

Siswa sekolah dasar sering melakukan kesalahan saat menuliskan ekspresi aljabar pola $k e-n$. Beberapa faktor yang mempengaruhi kesalahan tersebut seperti siswa sekolah dasar tidak menghitung penjumlahan sesuai langkah yang ditentukan saat menghitung banyak pola yang ditanyakan pada soal sehingga mengakibatkan terjadi kesalahan saat menuliskan ekspresi aljabar pola $k e-n$ pada ketentuan soal (Gunawan dkk., 2019; Khashan, 2014; Winarso \& Toheri, 2021).

Siswa sekolah dasar tidak melanjutkan menyajikan konsep pola bilangan dalam bentuk gambar seperti proses yang dilakukan sebelumnya dan tidak memahami konsep aljabar pada penggunaan pola bilangan saat menuliskan ekspresi aljabar. Hal ini sesuai dengan penelitian Vanscoy (2019) dan Wiest \& Amankonah (2021). Sebagaimana hasil temuan Levin (2018) yang menyebutkan bahwa kurangnya keahlian dalam konten matematika seringkali menjadi hambatan untuk memecahkan masalah aljabar. Sehingga, siswa di sekolah dasar perlu diberikan dasar teori pembelajaran aljabar dengan menggunakan karakterisasi pendekatan aritmatika dan pendekatan aljabar (AlMutawah dkk., 2019; Serbin dkk., 2020; Vanscoy, 2019).

Dengan demikian ditemukan bahwa siswa sekolah dasar dapat menggeneralisasi pola bilangan, namun masih banyak kesalahan konseptual dan prosedural yang dilakukan. Pada pengelompokkan berdasarkan tingkat pemecahan masalah, siswa dengan kategori rendah dan sedang cenderung melakukan kesalahan konseptual dalam hal kesalahan menggunakan konsep operasi hitung dan konsep bentuk ekspresi aljabar. Sementara siswa dengan kategori tinggi melakukan kesalahan prosedural dalam hal rendahnya pemahaman dalam aturan atau prosedur dalam proses generalisasi.

Adapun kelebihan penelitian ini adalah menemukan dan menganalisis bentuk-bentuk kesalahan konseptual dan prosedural yang dilakukan siswa sekolah dasar dalam menggeneralisasi 
pola berdasarkan tingkat pemecahan masalah. Namun, bentuk-bentuk kesalahan yang ditemukan masih didasarkan pada beberapa siswa sekolah dasar. Selain itu, penelitian ini belum mengidentifikasi secara generalistik hubungan antara pengetahuan dengan dan kesalahan konseptual dan prosedural siswa dalam menggeneralisasi pola berdasarkan tingkat pemecahan masalah. Oleh karenanya, disarankan bagi penelitian berikutnya untuk melakukan analisis secara statistik antara hubungan atau pengaruh pengetahuan konseptual dan prosedural siswa sekolah dasar terhadap tingkat kesalahan yang dilakukan berdasarkan tingkat pemecahan masalah siswa.

Implikasi hasil penelitian ini membuktikan bahwa siswa sekolah dasar memiliki pengetahuan konseptual dan prosedural dalam menggeneralisasi pola masalah, meskipun penyelesaian matematisnya masih memiliki kesalahan konseptual dan prosedural. Sehingga, para pendidik dan praktisi perlu fokus dalam pengajaran materi secara konseptual dan membiasakan siswa sekolah dasar untuk taat dalam aturan-aturan dan prosedur matematis.

\section{KESIMPULAN DAN SARAN}

Berdasarkan paparan hasil penelitian ditemukan bahwa siswa dengan tingkat pemecahan masalah rendah melakukan kesalahan konseptual berupa salah konsep operasi hitung, salah dalam menggeneralisasi ekspresi aljabar, dan tidak melanjutkan pola generalisasi aljabar. Sementara, siswa dengan tingkat pemecahan masalah sedang melakukan kesalahan konseptual berupa salah konsep operasi hitung dan salah dalam menggeneralisasi ekspresi aljabar. Lalu, siswa dengan tingkat pemecahan masalah tinggi melakukan kesalahan prosedural dalam menggunakan aturan saat mencari banyak pola dan tidak melanjutkan proses pengerjaan, sehingga memperoleh hasil jawaban yang salah.

Hasil penelitian ini menunjukkan bahwa siswa sekolah dasar mampu melakukan generalisasi pola secara intuitif, meskipun disertai kesalahan konseptual dan prosedural. Hal ini berimplikasi pada pendidik atau akademisi untuk dapat meminimalisir kesalahan siswa sekolah dasar dalam menggeneralisasi pola, melalui stimulasi pengajaran berbasis masalah yang tidak hanya bersifat prosedural, namun lebih bersifat konseptual. Hasil penelitian ini dapat dilanjutkan pada tahap pengembangan pengetahuan konseptual dan prosedural dalam menggeneralisasi pola bilangan. Hal ini dapat dilakukan dengan mengajak siswa untuk memecahkan masalah melalui soal generalisasi pola bilangan dengan memperhatikan dan memahami konsep operasi hitung yang benar, mendorong siswa untuk menyelesaikan soal dengan runtut dan menggunakan aturan dengan benar, sehingga dapat meningkatkan pengetahuan konseptual dan prosedural siswa.

\section{DAFTAR PUSTAKA}

Al-Mutawah, M. A., Thomas, R., Eid, A., Mahmoud, E. Y., \& Fateel, M. J. (2019). Conceptual understanding, procedural knowledge and problem-solving skills in mathematics: High school graduates work analysis and standpoints. International Journal of Education and Practice, 7(3), 258-273.

https://doi.org/10.18488/journal.61 .2019.73.258.273

Amir, M. F. (2015). Pengaruh pembelajaran konstektual terhadap kemampuan pemecahan masalah 
DOI: https://doi.org/10.24127/ajpm.v10i3.3713

matematika siswa sekolah dasar. Prosiding Seminar Nasional Pendidikan FKIP Universitas Muhammadiyah Sidoarjo, 01(07).

Andini, W., \& Suryadi, D. (2017). Student Obstacles in Solving Algebraic Thinking Problems. Journal of Physics: Conference Series, 895(1). https://doi.org/10.1088/17426596/895/1/012091

Apsari, R. A. (2015). Penelusuran Pola Tervisualisasi Untuk Mengembangkan Kemampuan Berpikir Aljabar. Proceedings Seminar Nasional FMIPA Undiksha V, 199-204.

Badjeber, R., \& Mailili, W. H. (2019). Profil Pengetahuan Konseptual Matematis Siswa SMP Ditinjau Dari Gaya Kognitif. ANARGYA: Jurnal Ilmiah Pendidikan Matematika, 2(1). https://doi.org/10.24176/anargya.v 2i1.3080

Bennett, A., Burton, L., \& Nelson, T. (2012). Mathematics for Elementary Teachers (S. K. Mattson (ed.); Previous). Connect Learn Succeed.

Bongala, J. (2020). Factors Affecting Students, Performance in Generalizing Algebraic Patterns Factors Affecting Students Performance in Generalizing Algebraic Patterns. October, 3048.

Cavey, L. O., \& Lowenthal, P. R. (2016). Calculus Students 'Ideas About Functions : Identifying Opportunities to Support Teacher Learning. In Mathematical Knowledge for Teaching (hal. 523). Thirty-Eighth Annual Meeting of the North American Chapter of the International Group for the Psychology of Mathematics
Education by International Group of the Psychology of Mathematics Education.

Creswell, J. W. (2012). Educational Research Planning, Conducting and Evaluating Quantitative and Qualitative Research (Fourth, Vol. 148). Boston: Pearson Education, Inc.

Crooks, N. M., \& Alibali, M. W. (2014). Defining and measuring conceptual knowledge in mathematics. Developmental Review, 34, 344-377. https://doi.org/10.1016/j.dr.2014.1 0.001

Dintarini, M., Putri Rosyadi, A. A., Susanti, R. D., \& Ummah, S. K. (2018). Analisis Kesalahan Siswa SMK Muhammadiyah 2 Malang Dalam Menyelesaikan Soal Bilangan Berpangkat Matematika. JPIn: Jurnal Pendidik Indonesia, 1(April). https://doi.org/10.47165/jpin.v1i1. 4

Elif, E. A., Ayten, O., \& E, M. O. (2015). An examination in Turkey: Error analysis of Mathematics students on group theory. Educational Research and Reviews, $10(8), \quad 10$. https://doi.org/10.5897/err2015.23 29

Girit, D., \& Akyuz, D. (2016). Algebraic Thinking in Middle School Students at Different Grades: Conceptions about Generalization of Patterns Dilek. Necatibey Egitim Fakultesi Elektronik Fen ve Matematik Egitimi Dergisi, 10(2), 243-243. https://doi.org/10.17522/balikesirn ef. 277815

Gunawan, W., Degeng, I. N. S., Utaya, S., \& Sulton. (2019). The improvement of conceptual and 
DOI: https://doi.org/10.24127/ajpm.v10i3.3713

procedural understanding by scaffolding with responsiveness. International Journal of Innovation, Creativity and Change, 12(1), 161.

Hiebert, J. (1986). Conceptual And Procedural Knowledge: The Case Of Mathematics (J. Hiebert (ed.)). Lawrence Erlbaum Associates, Inc.,

Khashan, D. K. H. (2014). Conceptual and Procedural Knowledge of Rational Numbers for Riyadh Elementary School Teachers. Journal of Education and Human Development, 3(Desember). https://doi.org/10.15640/jehd.v3n4 a17

Krathwohl, D. R. (2002). A revision of bloom's taxonomy: An overview. Theory into Practice, 41(4), 212218.

https://doi.org/10.1207/s15430421t ip4104_2

Lenz, K., Dreher, A., Holzapfel, L., \& Wittmann, G. (2020). Are conceptual knowledge and procedural knowledge empirically separable? The case of fractions. British Journal of Educational Psychology, 90(3), 809-829. https://doi.org/10.1111/bjep.12333

Levin, M. (2018). Conceptual and Procedural Knowledge During Strategy Construction: A Complex Knowledge Systems Perspective. Cognition and Instruction, 36(3), 247-278.

https://doi.org/10.1080/07370008.2 018.1464003

Ling, C. Y., Osman, S., Daud, M. F., \& Hussin, W. N. W. (2019). Application of vee diagram as a problem-solving strategy in developing students' conceptual and procedural knowledge. International Journal of Innovative
Technology and Exploring Engineering, 8(10), 2796-2800. https://doi.org/10.35940/ijitee.J959 1.0881019

Mouhayar, R., \& Jurdak, M. (2016). Variation of student numerical and figural reasoning approaches by pattern generalization type, strategy use and grade level. International Journal of Mathematical Education in Science and Technology, 47(2), 197-215. https://doi.org/10.1080/0020739X. 2015.1068391

Ocal, M. F. (2017). The Effect of Geogebra on Students' Conceptual and Procedural Knowledge: The Case of Applications of Derivative. Higher Education Studies, 7(2), 67-78.

https://doi.org/10.5539/hes.v7n2p6 7

Papadopoulou, E. (2020). Recognizing pattern rules in an early childhood classroom: the role of manipulatives. Educaional Journal of the University of Patras UNESCO Chair, 7(2), 58-69.

Rachmawati, L. N., Cholily, Y. M., \& Zukhrufurrohmah, Z. (2021). Mathematics Communication Mistakes In Solving Hots Problems. Infinity Journal, 10(February).

https://doi.org/10.22460/infinity.v1 0i1.p69-80

Radford, L. (2018). The Emergence of Symbolic Algebraic Thinking in Primary School. ICME-13 Monographs, 1(Desember), 3-25. https://doi.org/10.1007/978-3-31968351-5_1

Rittle-Johnson, B., \& Schneider, M. (2014). Developing Conceptual and Procedural Knowledge of Mathematics. Oxford Handbook of 
DOI: https://doi.org/10.24127/ajpm.v10i3.3713

Numerical Cognition, 1, 11181134.

http://oxfordhandbooks.com/view/ 10.1093/oxfordhb/9780199642342. 001.0001/oxfordhb9780199642342-e-014

Rivera, F. D. (2018). Pattern Generalization Processing of Elementary Students: Cognitive Factors Affecting the Development of Exact Mathematical Structures. 14(9).

Rusdiana, M., Suriaty, M., Sutawidjaja, A., \& Irawan, E. B. (2017). Pattern Generalization by Elementary Students. Advances in Social Science, Education and Humanities Research, 100, 379381.

https://doi.org/10.2991/seadric17.2017 .82

Serbin, K. S., Sánchez Robayo, B. J., Truman, J. V., Watson, K. L., \& Wawro, M. (2020). Characterizing quantum physics students' conceptual and procedural knowledge of the characteristic equation. Journal of Mathematical Behavior, 58. https://doi.org/10.1016/j.jmathb.20 20.100777

Star, J. R., \& Stylianides, G. J. (2013). Procedural and Conceptual Knowledge: Exploring the Gap Between Knowledge Type and Knowledge Quality. Canadian Journal of Science, Mathematics and Technology Education, 13(April), 169-181. https://doi.org/10.1080/14926156.2 013.784828

Stewart, C., Root, M. M., Koriakin, T., Choi, D., Luria, S. R., Bray, M. A., Sassu, K., Maykel, C., O’Rourke, P., \& Courville, T. (2017). Biological Gender Differences in Students' Errors on Mathematics
Achievement Tests. Journal of Psychoeducational Assessment, 35(1-2).

https://doi.org/10.1177/073428291 6669231

Vanscoy, A. (2019). Conceptual and procedural knowledge: A framework for analyzing point-ofneed information literacy instruction. Communications in Information Literacy, 3(2). https://doi.org/10.15760/comminfo lit.2019.13.2.3

Wiest, L. R., \& Amankonah, F. O. (2021). Conceptual versus procedural approaches to ordering fractions. European Journal of Science and Mathematics Education, 7, 61-72. https://doi.org/10.30935/scimath/9 534

Winarso, W., \& Toheri, T. (2021). An analysis of students' error in learning mathematical problem solving: The perspective of David Kolb's theory. Turkish Journal of Computer and Mathematics Education, 12(1), 139-150. https://doi.org/10.16949/turkbilmat .753899

Zulnaidi, H., \& Zakaria, E. (2012). The effect of using GeoGebra on conceptual and procedural knowledge of high school mathematics students. Asian Social Science, 8(11), 102-106. https://doi.org/10.5539/ass.v8n11p 102 